\title{
COMPETENCY-BASED APPROACH AS AN INTEGRAL PART OF THE BUSINESS HUMAN RESOURCES SYSTEM
}

\author{
Tymoshyk V.Yu. \\ Zaporizhzhia National University \\ Ukraine, 69600, Zaporizhzhia, Zhukovsky str., 66
}

vaileria1306@rambler.ru

Key words:

competencies, competence, competence model, competency-based approach, system of Human Resources management.

\author{
ORCID 0000-0003-0181-2898
}

In today's fast-paced economy, businesses have to be more ambitious in setting their goals and developing new strategies in order to survive and succeed. Implementing organization's business strategies is impossible without qualified, motivated and engaged employees who hold the unique set of competencies; as the professional and personal potential of workforce is a key factor in improving organization's efficiency in the face of dynamic and diverse changes of the market. In recent years a competency-based approach has become an integral part of the businesses' Human Resources (HR) management system. Today companies believe that employees, as a strategic asset, should be, first of all competent - i.e. have the knowledge, skills and behaviours necessary for the effective performance in that organization. The main feature of the competency-based approach in HR management is transition from staff-related operational issues to tasks of a higher strategic importance. Nowadays, statuary and mandatory training and the code of conduct are insufficient for improvement of labour efficiency and business performance and therefore, managers must pay particular attention to employees' personal development, engagement and motivation. Therefore, a competencybased approach formulates goals in a way that leads to improvement of business performance by achieving better results, changing employee behaviour, increasing productivity and efficiency of the organization. The aim of this article is to underline the importance of prompt implementation of the competency-based approach in the HR management system. We determined the essence and value of the competency-based approach to the formation of HR system and defined the concept of a "competency model". We investigated the approaches to developing a competency model as part of HR management and analysed its stages of formation. This article outlines the methods of creating competency models and their assessment criteria as well as explaining the difference of competency models to other traditional approaches. The relationship of the competency model with other areas of HR system was examined.

\section{КОМПЕТЕНТНІСНИЙ ПІДХІД ЯК СКЛАДОВА ЧАСТИНА КОНЦЕПЦІЇ УПРАВЛІННЯ ТРУДОВИМИ РЕСУРСАМИ НА ПІДПРИЄМСТВІ}

\section{Тимошик В.Ю.}

\author{
Запорізький національний університет \\ Україна, 69600, м. Запоріжжя, вул. Жуковського, 66
}

\begin{abstract}
Ключові слова:
компетенція, компетентність, модель компетенцій, компетентнісний підхід,
\end{abstract} система управління тудовими ресурсами.
В умовах жорсткої конкуренції підприємства ставлять перед собою більш грандіозні цілі та розробляють нові стратегії, щоб вижити на ринку. I реалізація бізнес-стратегій будь-якого підприємства неможлива без кваліфікованих, мотивованих працівників з унікальними компетенціями, професійний та особистісний потенціал яких $є$ ключовим фактором підвищення ефективності підприємства в умовах динамічних та різноманітних змін у зовнішньому середовищі. Останнім часом підхід, заснований на компетентності, став невід'ємною частиною системи управління персоналом підприємства. Сьогодні підприємства вважають, що персонал як стратегічний актив повинен мати насамперед компетенцію знання, уміння та поведінку, необхідні для ефективного виконання роботи на підприємстві. Головною особливістю компетентнісного підходу в управлінні персоналом $є$ перехід від оперативних проблем специфіки персоналу до завдань вищого стратегічного рівня. Зараз недостатньо просто навчати працівників, створювати правила поведінки та розробляти деякі норми, результатом усіх управлінських дій повинно бути підвищення ефективності праці, залучення персоналу, мотивація, а отже, підвищення загальної ефективності організації. Тому цілі підходу, заснованого на компетентності, сформульовані так, щоб показати, що ці процеси можуть поліпшити діяльність організації шляхом досягнення кращих результатів, зміни поведінки працівників, підвищення продуктивності та ефективності 
організації. У статті доведено актуальність та необхідність застосування компетентнісного підходу в системі управління трудовими ресурсами підприємств. Визначено сутність та значення компетентнісного підходу до формування системи управління персоналом. Обгрунтовано поняття «модель компетенцій». Розглянуто підходи до визначення компетенції та компетентності в системі управління персоналом. Проаналізовано стадії створення моделі компетенції та запропоновано модель іiі формування. Проаналізовано сутність компетентнісного підходу в системі управління трудовими ресурсами. Відзначено особливість і відмінність від існуючих традиційних піходів. Визначено методи створення моделей компетенцій $\mathrm{i}$ критерії їхньої оцінки. Розглянуто взаємозв'язок моделі компетенцій 3 іншими галузями системи управління трудовими ресурсами на підприємстві.

\section{Statement of the problem}

The workforce is one of the key components that determines the success of any business. The profitability and competitiveness of an enterprise are largely dependent upon its employees' knowledge and skillset, especially when the economy is unstable. This is why finding the most effective approach to the management of Human Resources (HR) is a particularly relevant issue. There is a myriad of both practical and theoretical methods of labour management, with competency-based approach being one of the most widely used.

\section{Analysis of recent studies and publications}

Many domestic and foreign researchers are devoted to the study of the effective HR management. Arapova O.M. [6], Basinskaya I.V. [2], Zaychenko O.I. [1], Zotkin A.O. [4], Ilchenko S.V considered grouping the main elements of the competency-based approach and interpreting this approach as a factor of competitiveness of the enterprise.

R. McCleland, R. Mills, M. Parkinson and Prahalad G. worked on approaches to developing competence models and formulating the concept of staff competence. O.A. Snitko [3], A.V. Sinichenko [5], O.A. Harun, Hemel, E., S. Hollyford developed the concept of core competencies of the organization. S. Widdet, O.L. Chulanova dedicated their work to using a competency-based approach to managing the organization's workforce.

\section{Objectives of the article}

The objective of this article is to analyse the main elements of a competency-based approach in management of human resources, to evaluate its effectiveness in relation to staff costs and competency model views, and explore the possibility of using the latter to assess employees and improve their efficiency.

\section{The main material of the research}

Economic transformations in society have significantly changed the relationship of enterprises and organizations with government bodies, production and other business partners as well as with employees directly. New economic and legal regulators are helping to change the relationship between the manager and subordinates, and between employees within the organization. As a result, there is a growing demand for HR management, where the human factor becomes a major factor in production [1].

Until recently, it was considered that stable and profitable activity of any enterprise required fixed and working capitals. But, if one figuratively imagines an enterprise as an integral intelligent living organism, then working capital acts as blood, fixed capital acts as a muscle, and human capital is its brain. A higher stage of brain development is required for a living organism to be higher up in the evolution hierarchy. Therefore, human and intellectual capital of the organization is critical to the business success, with engaged staff being a significant competitive advantage.

During the years of market economy existence, the methods of managing fixed capital, and most importantly working capital, have been developed. But the methodological approach to HR management needs constant improvement. This is due to a number of reasons.

The first reason being rapid technological innovation in products and processes that necessitates ongoing production training for staff, imposing greater demands on the professional and personal qualities of employees.

The second reason is a global change in the traditional education system. In 1999 the Ministers of Education of 29 countries agreed on a common vision of a European Higher Education Area and signed the Bologna Declaration, which now has 47 member countries.

Thirdly, in today's world, businesses of any type of ownership are subject to higher risk and require rapid adaptation to changes in the external environment.

In such circumstances, professional design of the enterprise development strategy and availability of highly qualified and competent staff are the most important and necessary factors for effective and successful activity, as a whole [2. p. 81].

There is a general belief that competence is the ability required to meet set goals and targets. Competence is a term that describes the person's knowledge of the intricacies of performing their duties, methods required for effective goal achievement and skills and competencies required at work. Competence means the ability to use one's knowledge and skills in the performance of functional duties. This is an integral characteristic of employees' ability to realize their potential through professional knowledge and work experience. As such, competence is a broader concept which includes competencies.

Competence is a functional concept that determines the implementation of an employee's competencies.

Competence is often the ability to meet certain standards of behaviour. In the practice of management, competence and competencies are interchangeable concepts.

The development of the theoretical foundations of strategic management that took into account a growing role of intellectual resources in creating sustainable competitive advantages of organizations led to the emergence of the concept of key competencies, by main leaders being G. Hemel and K. Prahalad. 
Hamel and Prahalad believe that the key to successful enterprise competition in the future is the formation, use and protection of key competencies.

Key competences, in contrast to physical assets that are deteriorating over time, are enhanced as they are applied in the exchange process. Thanks to them, models of diversification and market penetration can be studied [4].

The more distinctive or unique the core competency is, the more value it possesses.

From the workforce assessment point of view, the essence of a company's competency-based approach is to compare the quality, level of complexity and efficiency of work with the existing reference characteristics and competencies of a specific position. Therefore, it is very important for an enterprise to have a set of competencies that can fairly accurately describe the requirements for knowledge, skills, abilities, and behaviour within a specific position or group of related positions.

The main task of a competency-based approach is to enable the employee to manage his or her own skills and abilities. The peculiarity of the competency-based approach as a concept of HR management is the object of management. This concept brings forward the employee's potential: their ability, motivation and behaviour attitudes, rather than pre-existing knowledge and skills that do not always match the real need of the business. Unlocking the employee's potential gives them a powerful impetus to take active participation in the life of the organization, increases their job satisfaction, and forms the need to continuously improve knowledge, skills and competences.

Modern businesses increasingly apply a competencybased approach in HR management, with the competency model becoming the main link around which specific functional areas of HR management are concentrated. In fact, it can be argued that a competency-based approach is an integrated concept that forms the basic principles of HR management in a modern organization [5, p.291-292.]

A skilful implementation of competence models in all the above procedures leads to effective management decisions, which further contribute to the growth of workforce productivity and increase the enterprise profitability.

Competence Model is a general list of competencies that every member of staff within the organization should have. Each competency should be described in detail, and the competence model itself should reflect the businesses' standards of activity and behaviour norms.

At its core, the competence model describes human behaviour. That is, unlike the traditional criteria of assessment of "knowledge - lack of knowledge" and "ability - inability", when describing competencies, employee's behaviour is evaluated in terms of "does - does not". This approach largely avoids the subjectivity of evaluation (Fig. 1).

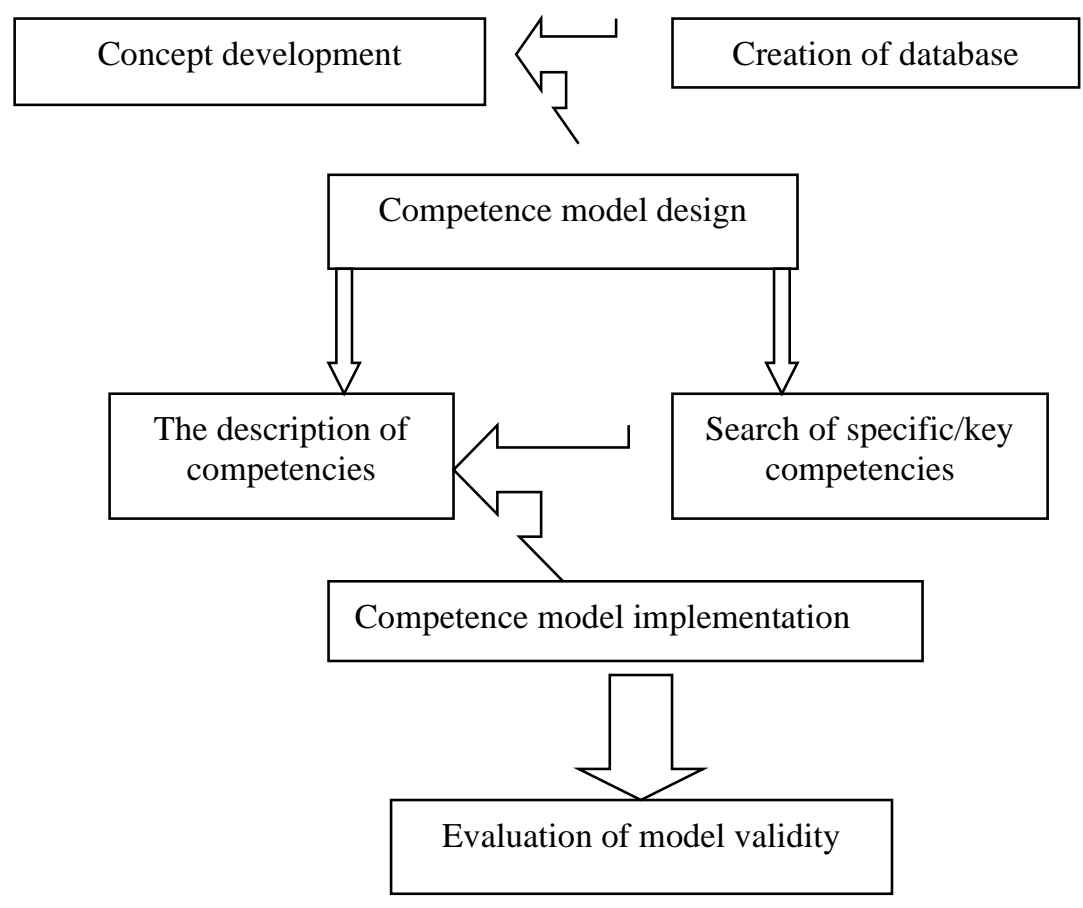

Fig.1. Formation of the competence model (developed by the author)

Concept development refers to the description of a purpose, methods, scope, timeframe and a desired outcome of the competency model.

- Creation of a database - selecting examples of standards of conduct and behaviour norms that ensure an effective performance of work in present and future.

- Competence model design is a selection of titles that match individual competencies. Work on a set of behaviour norms. Exclusion of duplication in standards of conduct. Determining the number of levels of competence model.

Evaluation of model validity -feedback from a wide range of specialists who check how competencies distinguish between efficient and less efficient work.

The model will be of great benefit provided it has been designed correctly, kept up-to-date after it had been put 
into practice with model users being provided a continuous support. The HR management based on welldesigned competencies will bring employees' behaviour to the set standards. Inspiration alone cannot be relied upon during the development of the appropriate competence model. Competence model development requires precise and skilful work. Special abilities and sophisticated analysis techniques are required to accomplish this task.

It is difficult to say which single approach is best for the development of competence models as there are so many analysis methods and organization options. As such, the competence model can be created in two ways.

The first approach is to implement a ready-made model in a specific organization. These models are based on research findings from management experience of leading companies, usually foreign ones.

The second way is to create a competence model from scratch. It can be done either with an aid of external consultants or created internally. The choice of method will depend on several factors including: the amount of time and money the company is prepared to spend on developing competence model, how well it understands the work process required, and the level of detail in which the company wants to understand the competence model in order for it to be a well-utilized tool with costs justified. Effort put into data collection, analysis and model design should result in a competence model tailored specifically to the employees of the organization around which the company's HR system is built. There is a certain number of criteria a competence model needs to meet in order to be deemed effective as formulated by M. Parkinson. The effective competence model is:

1) Comprehensive. The list of competencies should completely cover all the important aspects of the business. This is easily achieved through 10-12 competencies.

2) Precise. Specific competency should relate to a concrete activity that can be clearly separated from other activities. If competencies overlap, it will be difficult to accurately evaluate the employee's performance.

3) Targeted. Each competency should be clearly defined and not require effort to cover a broad field of practice.

4) Straightforward. Each competency must be formulated in an accessible manner, so it can be universally utilized.

5) Congruent. Competencies should strengthen the organizational culture and reinforce the company's longterm goals. If competencies seem too abstract, they will not be useful to or utilized by managers.

6) Contemporary. The competency system must be up-to-date and reflect the true and foreseeable needs of the organization. Like any method of work analysis, it will require input from those with a strategic vision [6, p.210-211]

A competence model influences such business aspects as recruitment, staff training, development and motivation.

In terms of staff assessment, a competence model allows the development of job requirements; and the assessment of staff competence levels by comparing the current state of competencies with the previous state and with the required state. When using this model, the assessment is carried out using uniform standards, which facilitates comparative analysis if necessary.
In regards to recruitment, a competence model allows formulation of the person specification against which potential candidates are evaluated. According to the assessment, the candidates' competence can be characterized as full and partial. Based on such findings, reasonable conclusions can be made about the candidate's suitability for the position and appropriate recruitment decisions can be made.

With respect to career management, a competence model can be used to form a reserve pool of candidates by comparing their current competencies with standard requirements for the respective potential positions.

Regarding staff training and development, a competence model allows to make accurate and reasonable conclusions on necessary directions to employee training and to prepare their individual development plans. In order to make training decisions, it is sufficient to compare the current level of employee competence development to the target level. In addition, a competence model enables comprehensive research on the effectiveness of staff training.

\section{Conclusions}

Thus, a competence model should be understood as a general list of competencies that all the staff of the organization must have. It is important to take into account the fact that each competency must be assigned a detailed description, and a competence model itself should reflect the company's mandatory performance standards and standards of conduct.

At present, many modern enterprises define the important role of staff competence (knowledge, skills, abilities) in improving the efficiency of their business processes and achieving high results. The practice of applying a competency-based approach in managing an organization proves the need for constant refinement of competencies for a wide variety of staff under the influence of external and internal organizational changes.

Therefore, until recently, HR management was considered a mandatory expense rather than a valuable resource for businesses. The economic value is usually associated with fixed capital - equipment, technology, technical capabilities. The business expansion is not only limited by the availability of working capital, but also by access to skills and creativity - human capital [1, p.10].

A competency-based approach as a tool for HR management gives a clear definition of the professional and behavioural requirements that are imposed on the employee, depending on their managerial level, profession, position and tasks performed. Competencies serve as a criterion for choosing appropriate training for each staff member.

A competitive ability of the enterprise can be greatly improved by using the examples of successful application of a competency-based approach in HR management.

Thus, the evolution of the organization's HR management approaches has had a significant impact on the modern workforce system formation. The system of staff assessment distinguished its subject of evaluation at each evolutionary stage. At this point, the assessment is focused on the personal qualities of an employee, their behaviour and performance results. In addition, the role of staff 
assessment in HR management has changed, becoming its main function in close collaboration with others.

Therefore, people are critical to organizational success, and the labour and intellectual capital of the enterprise workforce provides the opportunity for significant competitive advantage. HR management is critical to the success of the enterprise because human capital has certain qualities that make it valuable. In terms of business strategy, any business can succeed if it has a sustainable competitive advantage and can maintain it for a long time. Therefore, it can be concluded that human capital resource is crucial for provision of the competitive advantage to the enterprise.

\section{References}

1. Zaichenko, O. I., Kyznetsova, V.I. (2015). Upravlsnnya ludskimi resyrsami [Human resources management]. Ivano-Frankivsk: Lileya NV

2. Basinskaya, I.V. (2013). Kompetentnostny j podkhod v upravlenii chelovecheskimi resursami [Competency-based approach to human resource management]. Gumanitarno-ekonamichnij visnik: navukovo-tearetichnij chasopis, 3, 81-87

3. Snitko, O.A. (2013). Kompetentnostny`j podkhod k upravleniyu resursami organizaczii [Competency-based approach to organization resource management]. Vestnik Belgorodskogo universiteta kooperacii ekonomiki i prava - Bulletin of the Belgorod University of the Cooperation of Economics and Law, 2, 340-346.

4. Zotkin, A.O, Natejkina, Yu.O. Kompetentnestnyi pidkhid v upravlinni personalom [Competent approach in personnel management]. Retrieved from https://research-journal.org/economical/kompetentnostnyj-podxod-vupravlenii-personalom

5. Sinichenko, A.V. (2016). Kompetentnisnyi pidkhid yak suchasna paradyhma upravlinnia personalom [Competency - based approach as a modern paradigm of personnel management]. Finansy, uchet, banki Finance, accounting, bank, 1, $288-294$

6. Arapova, O.M. (2013). Kompetentnisnyi pidkhid yak chynnyk pidvyshchennia konkurentospromozhnosti pidpryiemstva [Competency - based approach as a factor in increasing the competitiveness of an enterprise]. Ekonomika: realiyi chasu - Economy: real hour, 1, 207 - 211 